\title{
A LOOK AT SIMULATION THROUGH A STUDY ON PLANKTON POPULATION DYNAMICS
}

C. R. Cole

August 1967

\section{AEC RESEARCH \& DEVELOPMENT REPORT}




\title{
LEGAL NOTICE
}

This repott wos prepared as an gccount of Goverrimenl sponsared work. Neither the United States nor the Commission, nor any person acting on beholf of the Commissiont

A. Makes ony wartanty or representation, expressed or implled, with respect fo the occuracy, com: pleteness, or usefulness of the information contained in this repart, or that the use of any information. opparotus, method, of procens disclosed in this report moy nat infringe privotoly owned righty or:

B. Asrumes any, liabilitias with respect to the $0 s 6$ of or for damages resulting frots the use of any infarmation, opparatus, method, or process disclosed in this ceport?

As used in the obove. "person actitis on behalf of the Coniminsien" includes amy employse on contractor of the Cammitian or employen of such cantroctot, to the extent that sust emplayte or con. fractor of the Commission, or einployse of such cantractor pteporten, disteminates, of provides accets 10 , any information pursuant to his employment of controct with the Commission, or his employment with such centracior:

\author{
PACIFIC NORTHWEST LABORATORY \\ ECHLAND, Washisctor \\ oporated by \\ BATTELLE MEMORIAL INSTITUTE \\ for the
}

UNITED STATES ATOMIC ENERGY COMMISSION UNDER CONTRACI AT(45-1)-1830 


\title{
33679000606220
}

$$
\text { BNWL- } 485
$$

UC-48, Biology

and Medicine

\section{A LOOK AT SIMULATION THROUGH A STUDY ON PLANKTON POPULATION DYNAMICS}

\author{
By \\ C. R. Cole \\ Computers and Control Section \\ Applied Physics and Electronics Department
}

August , 1967

PACIFIC NORTHWEST LABORATORY

RICHLAND, WASHINGTON 
Printed in the United States of America Available from

Clearinghouse for Federal Scientific and Technical Information National Bureau of Standards, U.S. Department of Commerce Springfield, Virginia 22151

Price: Printed Copy $\$ 3.00 ;$ Microfiche $\$ 0.65$ 


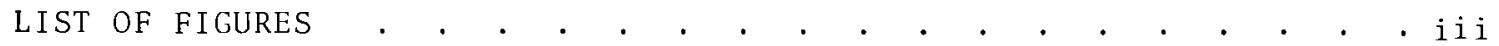
ABSTRACT . . . . . . . . . . . . . . . . . . . . 1 INTRODUCTION $\cdot$ • SUMMARY AND CONCLUSIONS . . . . . . . . . . . . . . . . . 2 DISCUSSION AND RESULTS . . . . . . . . . . . . . . . . . 2

\section{$\underline{\text { LIST OF FIGURES }}$}

1 Block Diagram Showing the Relationships Between the Variables in the Simulation of Plankton Population Dynamics

2 Graph Showing the Annual Cycle of Estuarine Phytoplankton and Zooplankton

3 Graph Showing the Annual Cycle of Estuarine Phytoplankton and Zooplankton with Parameters Adjusted so that $\mathrm{I}$ and $\mathrm{T}$ are in Phase

4 Graph Showing the Annual Cycle of Estuarine Phytoplankton and Zooplankton with Parameters Adjusted so that the Mean Average Temperature was $15.5^{\circ} \mathrm{C}$ rather than $15^{\circ} \mathrm{C}$

5 Graph Showing the Annual Cycle of Estuarine Phytoplankton and Zooplankton with Parameter Values Adjusted so that the Temperature Varies $\pm 8^{\circ} \mathrm{C}$ Rather than the Normal $\pm 9{ }^{\circ} \mathrm{C}$

6 Graph Showing the Annual Cycle of Estuarine Phytoplankton and Zooplankton with Parameter Values Adjusted so There is an $8 \%$ Increase in Phytoplankton Death Rate

7 Graph Showing the Annual Cycle of Estuarine Phytoplankton and Zooplankton with Parameter Values Adjusted so There is a $12 \%$ Increase in Zooplankton Death Rate

8 Graph Showing the Annual Cycle of Estuarine Phytoplankton and Zooplankton with Parameter Values Adjusted so There was an $8 \%$ Increase in Nutrient Influx

9 Block Diagram Showing the MIDAS Digital Simulation of this Plankton Ecocycle

10 Sample Program Listing and Output of the MIDAS Simulation Diagrammed in Figure 9

11 Diagram Showing the Analog Circuit Used in the Simulation of Plankton Population Dynamics 


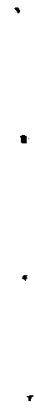




\title{
A LOOK AT SIMULATION THROUGH A STUDY
}

ON PLANKTON POPULATION DYNAMICS

C. R. Cole

\section{ABSTRACT}

\begin{abstract}
The annual cycle observed in the population dynamics of estuarine phytoplankton and zooplankton was simulated according to the model developed by Davidson and clymer. This simulation demonstrates the usefulness of analog computer modeling in studying ecological systems.

The report contains several examples in which the effect of parameter changes are predicted by the model. A typical result indicates that an increase in phytoplankton death rate increases the magnitude of the spring algal bloom. Results such as this, which contradict intuition, bring ecological mechanisms to light that might otherwise remain undiscovered.
\end{abstract}

\section{INTRODUCTION}

The annuai cycle observed in the population dynamics of estuarine phytoplankton and zooplankton was simulated according to the model developed by Davidson and Clymer. (1) The effects of various parameter changes were studied in order to demonstrate some of the benefits of ecosimulations.

Concern over the population explosion has aroused interest in the use of the algae of the ocean for a food base. An application of the "plankton simulation" described in this report could be the optimizing of a "harvest routine" for the plankton, which would result in the greatest harvest without destroying the ecosystem. The simulation could be expanded to describe the uptake and elimination of radioactive materials present in the ocean, and thus, the effects of using the ocean as a burial ground for radioactive wastes could be evaluated. The "plankton simulation" might be useful in describing the estuarial effects observed at the mouth of the Columbia River as well as predicting the level of radioactivity in the estuarine plankton. Additional ecological simulations of fish cycles, algal cycles, and other ecological cycles of the Columbia might result in the development of a reactor production cycle which would cause the least amount of radioactivity to enter man's food chain without destroying any of the ecosystems of the columbia.

Studies on the effects of sewage on water-carried disease bacteria and on river ecosystems could result in a simulation which would optimize sewage disposal from the standpoint of safety and economy. 


\section{SUMMARY AND CONCLUSIONS}

Initial studies on the plankton simulation indicated that an increase in phytoplankton death rate increases the magnitude of the spring algal bloom (Figure 6). Similarly, the effects of increased zooplankton death rate (Figure 7), milder climate (Figure 8 ), and changes in the rate of nutrient influx (Figure 9) were studied.

In addition, the following benefits of an ecological simulation were discussed:

1. It provides an overall view of an ecological system.

2. It weighs each of the known ecological mechanisms involved and puts them in their proper place in the system.

3. It can provide new insight and thus stimulate the discovery of previously unnoticed mechanisms.

4. Once validated, it can serve as an invaluable tool for predicting the effects of parameter changes or in optimizing "a harvest routine," "a reactor production cycle," "a sewage disposal cycle," etc. It is hoped that this paper has demonstrated the usefulness of ecological simulation.

\section{DISCUSSION AND RESULTS}

The following assumptions were made by Davidson and Clymer(1) in formulating a mathematical model for the "Simulation of Plankton Population Dynamics."

"1. The locale is the Middle Alantic Seaboard of the United States.
2. All variables are uniformly distributed through the volume of water of concern.

3. Al] variables are averages over 24 hours, since diurnal frequencies were not of interest.

4. All species can be lumped into two classes: phytoplankton and zooplankton, each having constants averaged over all species, ages, and times of year.

5. There is only one critical nutrient.

6. Growth and reproduction need not be distinguished.

7. Illumination and water temperature have sinusoidal annual cycles."

Equations (1) through (5) resulted from the preceding assumptions. (The nomenclature for symbols in this dis cussion appear in Table I.)

$$
\begin{aligned}
\frac{1}{\mathrm{P}} \mathrm{P} & =\mathrm{K}_{1} \mathrm{~N}^{\mathrm{LIM}} \mathrm{IT}-\mathrm{K}_{2} Z-\mathrm{K}_{3}-\mathrm{K}_{4} \mathrm{~T} \\
\dot{\mathrm{Z}} & =\left(\mathrm{K}_{5} \mathrm{P}-\mathrm{K}_{6}\right) \mathrm{Z} \\
\dot{N} & =K_{7}-K_{8} \mathrm{P} \quad \mathrm{N} \geq 0 \\
\mathrm{~T} & =\mathrm{K}_{9}-\mathrm{K}_{10} \cos \frac{\pi \mathrm{t}}{6} \\
I & =K_{11}-K_{12} \cos \frac{\pi t}{6}
\end{aligned}
$$

Figure 1 shows a block diagram indicating the relationship between the variables in this simulation. Nutrient influx is assumed to be constant throughout the year and the nutrient is depleted at a rate proportional to the phytoplankton population level.

The phytoplankton population growth rate is determined by the phytoplankton population level and the rate of 
TABLE I. Nomenclature

\begin{tabular}{|c|c|c|c|}
\hline Symbo1 & Description & Value & Units \\
\hline I & $\begin{array}{l}\text { Incident solar and sky } \\
\text { radiation }\end{array}$ & & $m g-c a 1 / c m^{2}-m i n$ \\
\hline $\mathrm{K}_{1}$ & Phytoplankton growth rate & & $\mathrm{m}^{3}-\mathrm{cm}^{2}-\mathrm{min}$ \\
\hline & due to photosynthesis & 6.4 & $\overline{\mathrm{mo}-(\mathrm{mg} \text { at. }}$ wt) $-\mathrm{g}-\mathrm{ca} 1-{ }^{\circ} \mathrm{C}$ \\
\hline $\mathrm{K}_{2}$ & $\begin{array}{l}\text { Death rate of phytoplankton } \\
\text { eaten by zooplankton }\end{array}$ & 0.0015 & $\mathrm{~m}^{3} / \mathrm{mg}-\mathrm{mo}$ \\
\hline $\mathrm{K}_{3}$ & $\begin{array}{l}\text { A11 other contributions to } \\
\text { death and disappearance rate } \\
\text { of phytoplankton }\end{array}$ & 3.0 & $\mathrm{mo}^{-1}$ \\
\hline $\mathrm{K}_{4}$ & $\begin{array}{l}\text { Debit of energy needed for } \\
\text { respiration }\end{array}$ & 0.15 & $1 / \mathrm{mo}-{ }^{\circ} \mathrm{C}$ \\
\hline $\mathrm{K}_{5}$ & $\begin{array}{l}\text { Zooplankton growth rate } \\
\text { resulting from phytoplankton } \\
\text { consumption }\end{array}$ & 0.021 & $\mathrm{~m}^{3} / \mathrm{millions}$ of cells-mo \\
\hline $\mathrm{K}_{6}$ & Death rate of zooplankton & 4.0 & $\mathrm{mo}^{-1}$ \\
\hline $\mathrm{K}_{7}$ & $\begin{array}{l}\text { Rate of nutrient influx (due } \\
\text { to tides, bacterial action } \\
\text { and marine animal excreta) }\end{array}$ & 6.0 & $(m g$ at. wt $) / m^{3}-m o$ \\
\hline $\mathrm{K}_{8}$ & Nutrient bound by phytoplankton & 0.08 & $\frac{\mathrm{mg} \text { at. }}{\text { mo-militions of cells }}$ \\
\hline$K_{9}$ & Average annual temperature & 15.0 & ${ }^{\circ} \mathrm{C}$ \\
\hline $\mathrm{K}_{10}$ & $\begin{array}{l}\text { Maximum summer elevation } \\
\text { of temperature }\end{array}$ & 9.0 & ${ }^{\circ} \mathrm{C}$ \\
\hline$K_{11}$ & Average annual illumination & 0.22 & $\mathrm{~g}-\mathrm{ca} 1 / \mathrm{cm}^{2}-\mathrm{min}$ \\
\hline $\mathrm{K}_{12}$ & $\begin{array}{l}\text { Maximum summer elevation } \\
\text { of illumination }\end{array}$ & 0.10 & $g-c a 1 / c^{2}-\min$ \\
\hline $\mathrm{N}$ & Nutrient concentration & & $m g$ at. $w t / m^{3}$ \\
\hline$N^{L I M}$ & N 1imited from above & 0.5 & $\mathrm{mg}$ at. $w t / \mathrm{m}^{3}$ \\
\hline $\mathrm{P}$ & $\begin{array}{l}\text { Phytoplankton population } \\
\text { density }\end{array}$ & & $\frac{\mathrm{mi11ions} \text { of cel1s }}{\mathrm{m}^{3}}$ \\
\hline$t$ & time & $\begin{array}{l}\left(\begin{array}{l}0 \\
\text { at }\end{array}\right. \\
\text { Jan } 1)\end{array}$ & mo \\
\hline $\mathrm{T}$ & Temperature of water & & ${ }^{\circ} \mathrm{C}$ \\
\hline Z & $\begin{array}{l}\text { Zooplankton population } \\
\text { weight density }\end{array}$ & & $\mathrm{mg} / \mathrm{m}^{3}$ \\
\hline
\end{tabular}




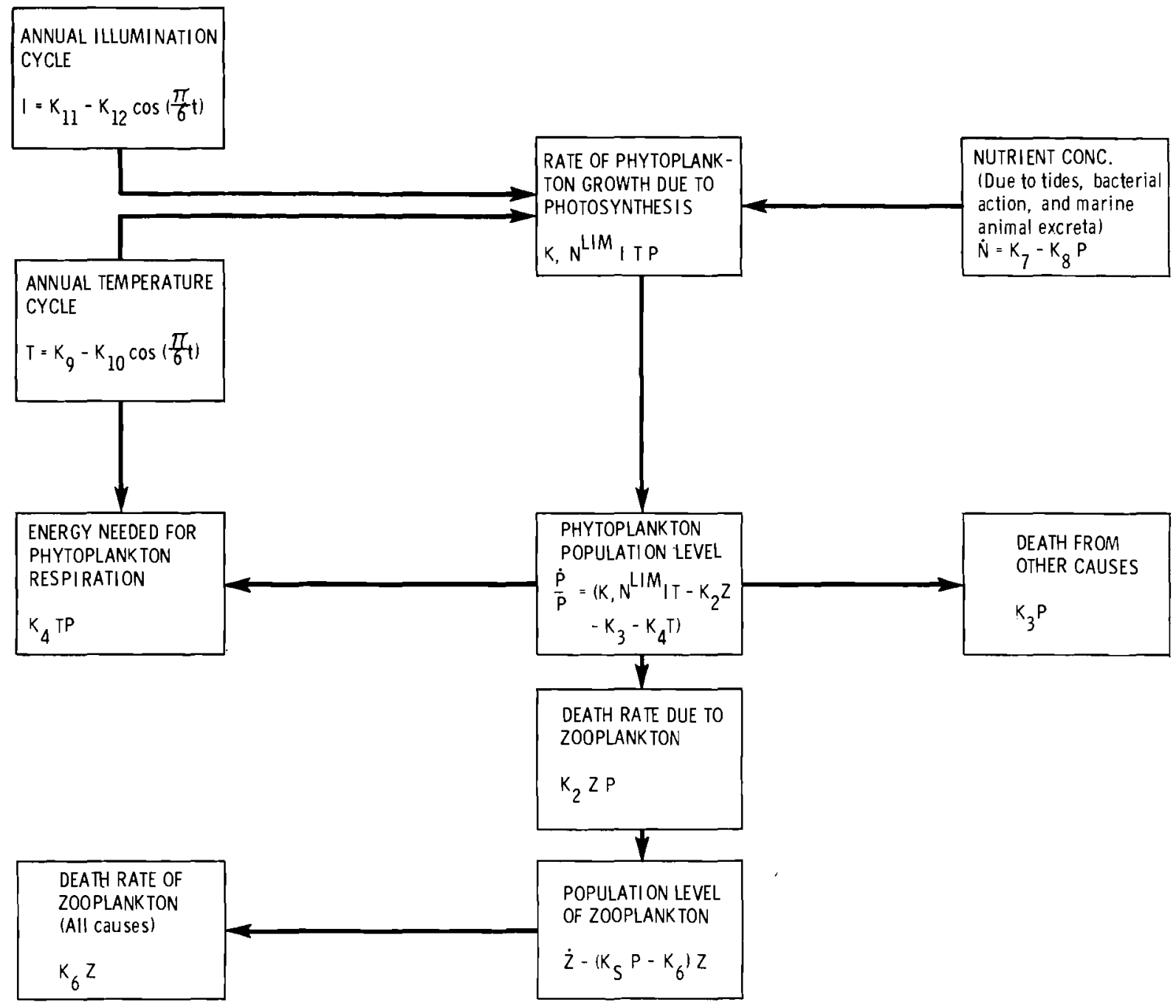

FIGURE 1. Block Diagram showing the

Relationships Between the Variables in the Simulation of Plankton Population Dynamies

photosynthesis, which is dependent on the illumination, temperature, and whether there is the proper amount of nutrient to support photosynthesis. The respiration energy needed to sup- port the phytoplankton population is taken to be a function of the temperature and population. The death rate of phytoplankton is attributed to two causes: Death rate due to being eaten 
by zooplankton and death rate due to natural and other miscellaneous causes. The death rate of phytoplankton due to zooplankton is assumed proportional to the zooplankton population while the death rate from other causes is assumed proportional to the phytoplankton population.

The zooplankton growth rate is assumed proportional to the phytoplankton population and zooplankton population (i.e., the more zooplankton there are, the faster they produce, as long as there is enough phytoplankton to eat). zooplankton death rate is lumped into one constant, and the death rate is proportional to zooplankton population.

Equations (1) through (5) were scaled and patched on the analog computer. Although the equations and constants for this simulation were obtained from Reference 1 , the dynamic range of $P$ and $Z$ were not given, so that various scale factors for $P$ and $Z$ had to be chosen until the proper dynamic range for $P$ and $Z$ was determined.

In order to demonstrate one facet of ecosimulation's many advantages, various parameters of this simulation were changed in order to demonstrate their effect on the yearly cycle.

Figure 2 shows the normal curves obtained with the parameter values indicated in Reference 1 . Notice that the "spring algal bloom" is about a factor of $10^{3}$ greater than the winter minimum and that it occurs about May 1, while the zooplankton reach their maximum about $11 / 2$ weeks later. Notice also that the nutrient concentration which had been building up all winter is depleted when the phytoplankton reach their peak.
In the normal simulation, it was assumed that $I$ and $T$ were out of phase, and the temperature reached its maximum one month later than the illumination reached its maximum. What effect would less phase difference between I and $\mathrm{T}$ have on the ecocycle? Figure 3 demonstrates an unreal situation (i.e., no phase difference), but the general effects shown are indicative of less phase difference between $I$ and $T$. The effects can be explained as follows: The "spring algal bloom" takes place at an earlier date because $\mathrm{I}$ and $\mathrm{T}$ are in phase and phytoplankton growth rate (due to photosynthesis) depends on the product IT. The magnitude of the winter population is lowered because $I$ and $T$ reach their minimums at the same time. The nutrient concentration increases to a much higher value during the lowered population levels of the winter, thus increasing the magnitude of the "spring algal bloom."

Figure 4 shows the effect of a higher average temperature. The increase was from 15 to $15.5^{\circ} \mathrm{C}$, but the seasonal variation remained at $\pm 9{ }^{\circ} \mathrm{C}$. The effects are as follows: The "spring algal bloom" occurs sooner, but is not as large in magnitude. This can be explained by the fact that the warmer winter allowed the normally reduced winter population to remain at a slightly elevated level, which in turn decreased the buildup of nitrient over the winter.

Figure 5 shows the effect of less temperature variation. The average temperature remained the same, but the variation was reduced from $\pm 9{ }^{\circ} \mathrm{C}$ to $\pm 8{ }^{\circ} \mathrm{C}$. The effects were earlier spring bloom, but lower in magnitude. 
P

(millions of ce $\left.11 \mathrm{~s} / \mathrm{m}^{3}\right)$

(Phytoplankton population density)

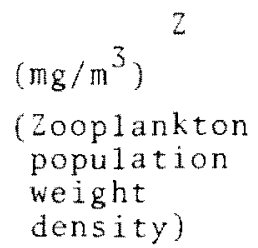

$N$

(mg at. wt $/ m^{3}$ )

Gutrient

concentration

$\left(\mathrm{g}-\mathrm{ca} 1 / \mathrm{cm}^{2} / \mathrm{min}\right)$

(Incident sky

and solar

radiation)

$\mathrm{T}$

$\left({ }^{\circ} \mathrm{C}\right)$

(Temperature)
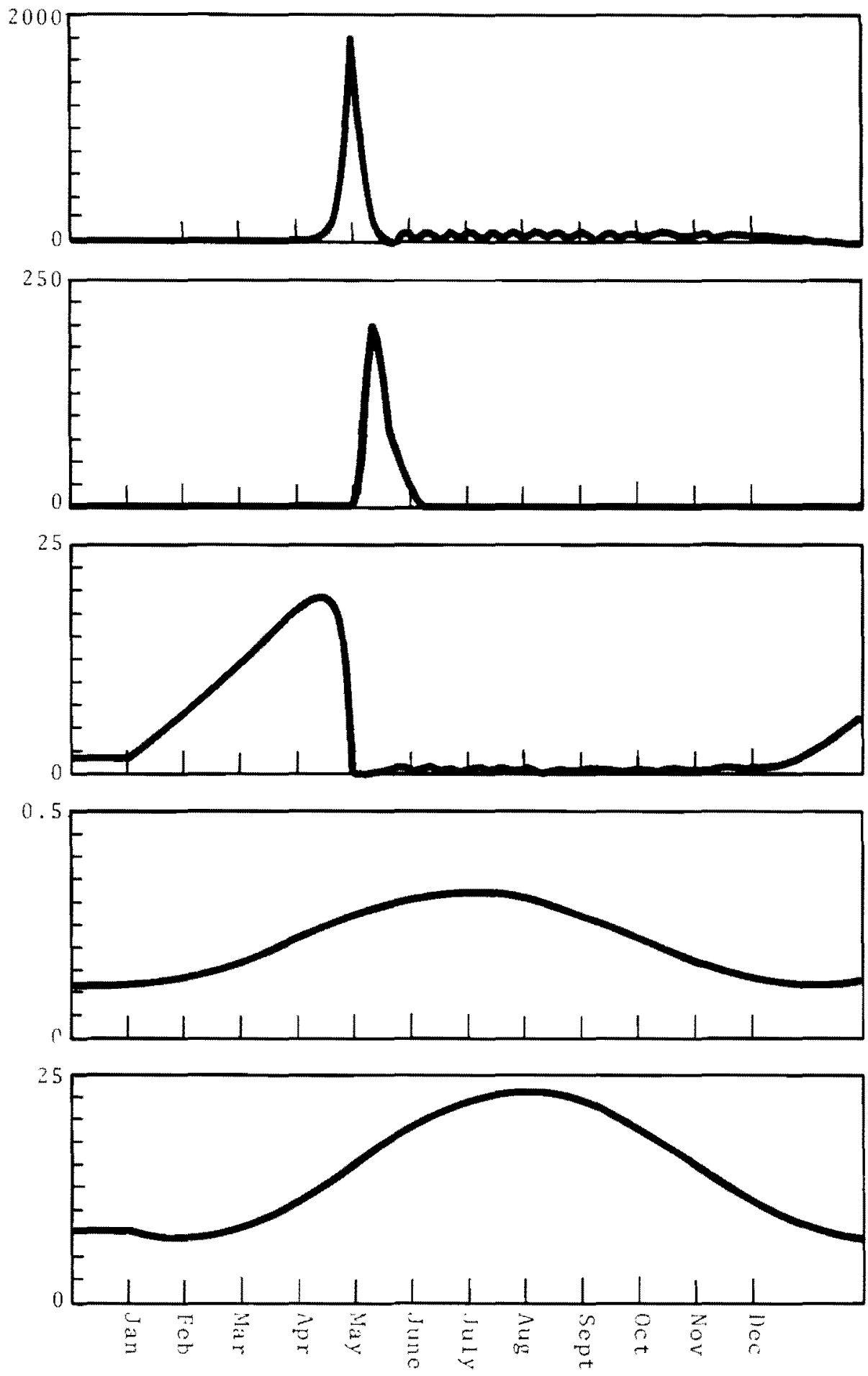

FICURE 2. Graph Showing the Anrual

Cycle of Estuarine Phytoptankton and

zooplankton. (The parameter values

used in this simulation were ob-

tained from Peference 1.) 


\section{$P$}

(millions of

cells $/ \mathrm{m}^{3}$ )

(Phytoplankton population density)

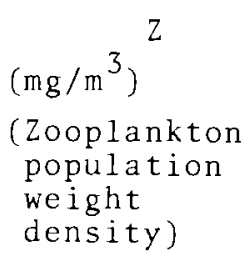

N

(mg at. wt $/ \mathrm{m}^{3}$ ) (Nutrient concentration)
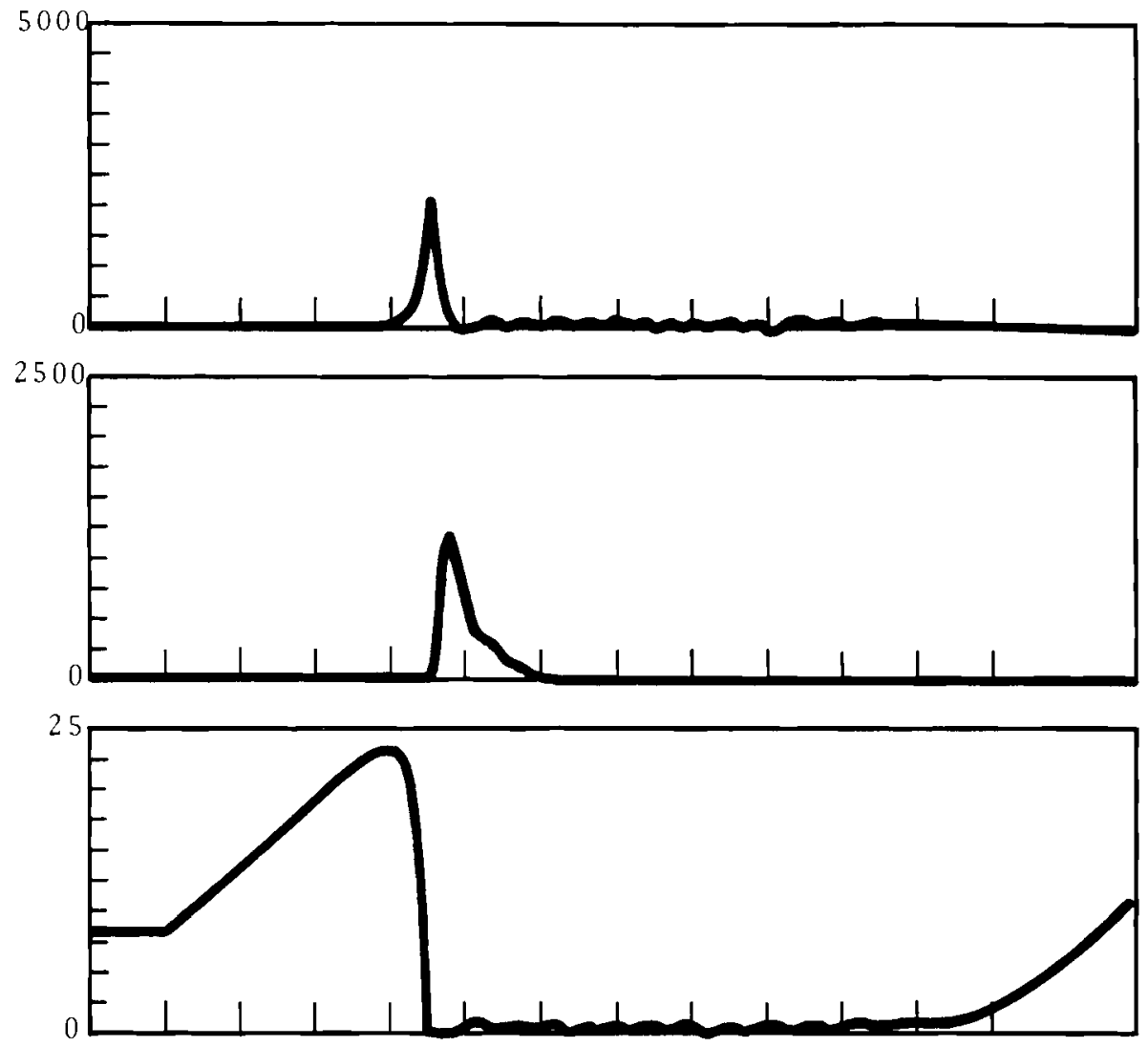

\section{I \\ $\left(\mathrm{g}-\mathrm{ca} 1 / \mathrm{cm}^{2} / \mathrm{min}\right)$ \\ (Incident sky and solar radiation)}

$\mathrm{T}$

$\left({ }^{\circ} \mathrm{C}\right)$

(Temperature)
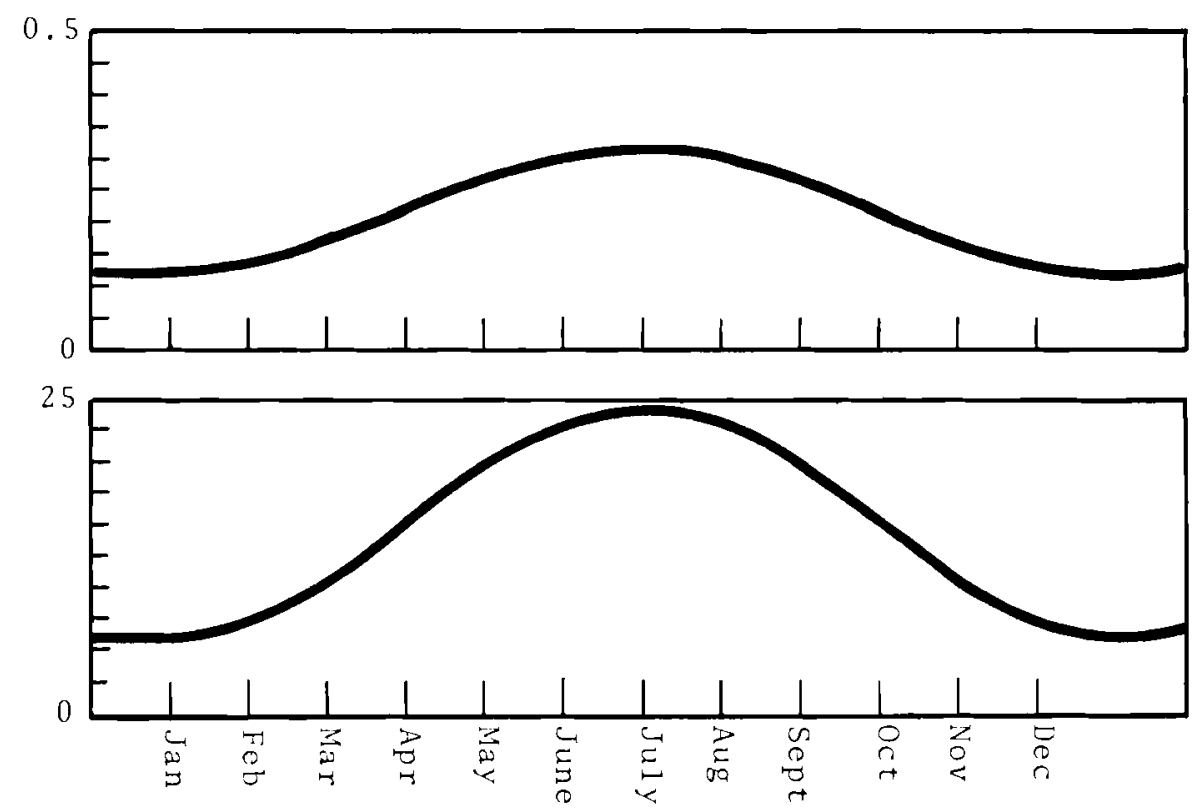

FIGURE 3. Graph Showing the Annual

Cycle of Estuarine Phytoplankton and Zooplankton with Parameters Adjusted so That $I$ and $T$ Are in Phase 
$\mathrm{P}$

(millions of cells $/ \mathrm{m}^{3}$ )

(Phytoplankton population denstiy)

\section{$\left(\mathrm{mg} / \mathrm{m}^{3}\right)^{2}$ \\ (Zooplankton population weight density)}

$\mathrm{N}$

(mg at. wt $/ \mathrm{m}^{3}$ )

(Nutrient

concentration)

\section{I}

$\left(\mathrm{g}-\mathrm{cal} / \mathrm{cm}^{2} / \mathrm{min}\right)$

(Incident sky and solar radiation)

$\mathrm{T}$

$\left({ }^{\circ} \mathrm{C}\right)$

(Temperature)
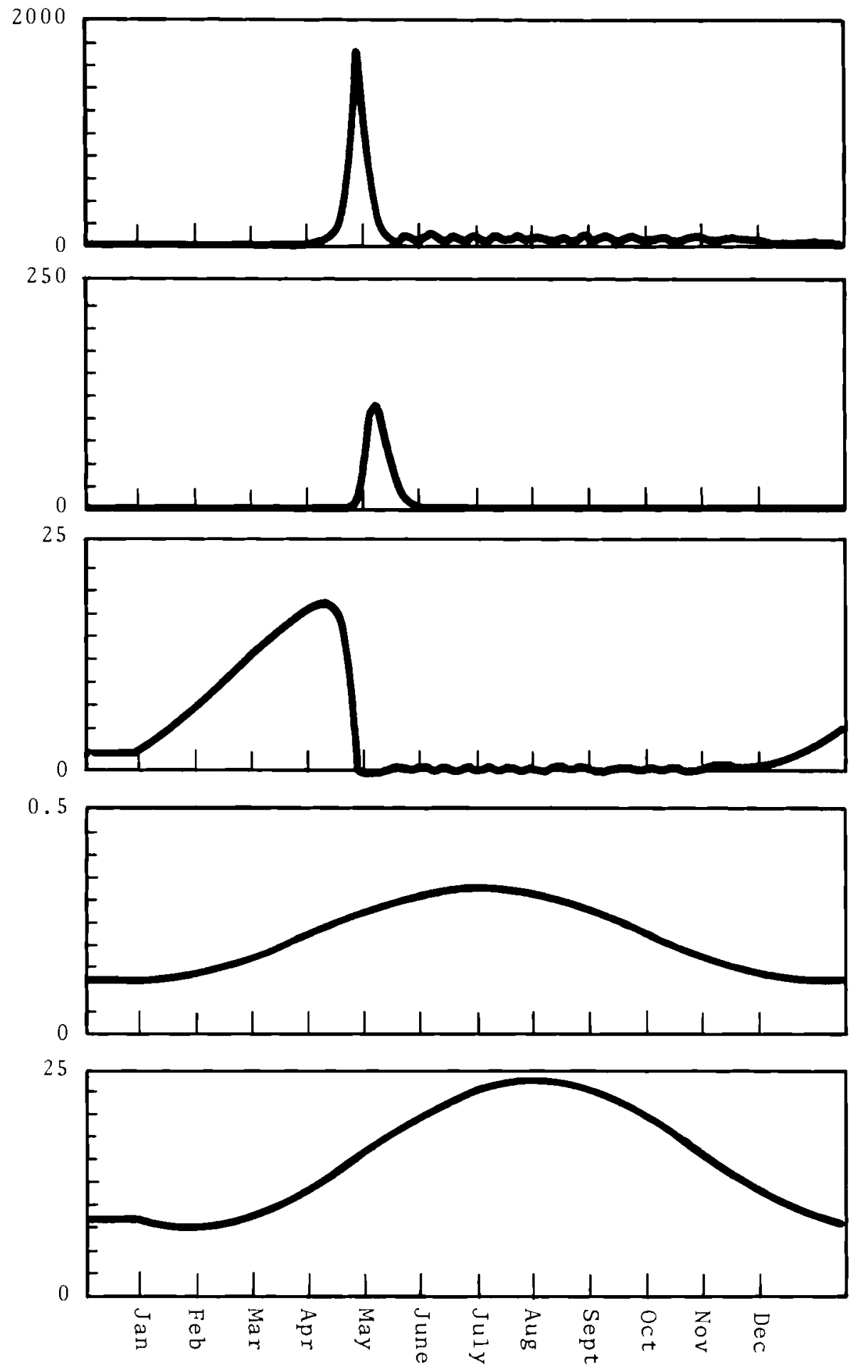

FIGURE 4. Graph Showing the Annual

Cycle of Estuarine Phytoplankton and

Zooplankton with Parameters Adjusted

so that the Mean Average Temperature

was $15.5^{\circ} \mathrm{C}$ Rather than $15^{\circ} \mathrm{C}$ 
$\mathrm{P}$

(militons of ce $11 \mathrm{~s} / \mathrm{m}^{3}$ )

(Phytoplankton population density)

$$
\begin{aligned}
& \left.{ }_{\left(\mathrm{mg} / \mathrm{m}^{3}\right.}\right)^{2} \\
& (\text { zooplankton } \\
& \text { population } \\
& \text { weight } \\
& \text { density) }
\end{aligned}
$$

$\mathrm{N}$

(mg at. wt $/ \mathrm{m}^{3}$ )

(Nutrient concentration)

I

$\left(\mathrm{g}-\mathrm{ca} 1 / \mathrm{cm}{ }^{2} / \mathrm{min}\right)$

(Incident sky and solar radiation)

$\mathrm{T}$

$\left({ }^{\circ} \mathrm{C}\right)$

(Temperature)
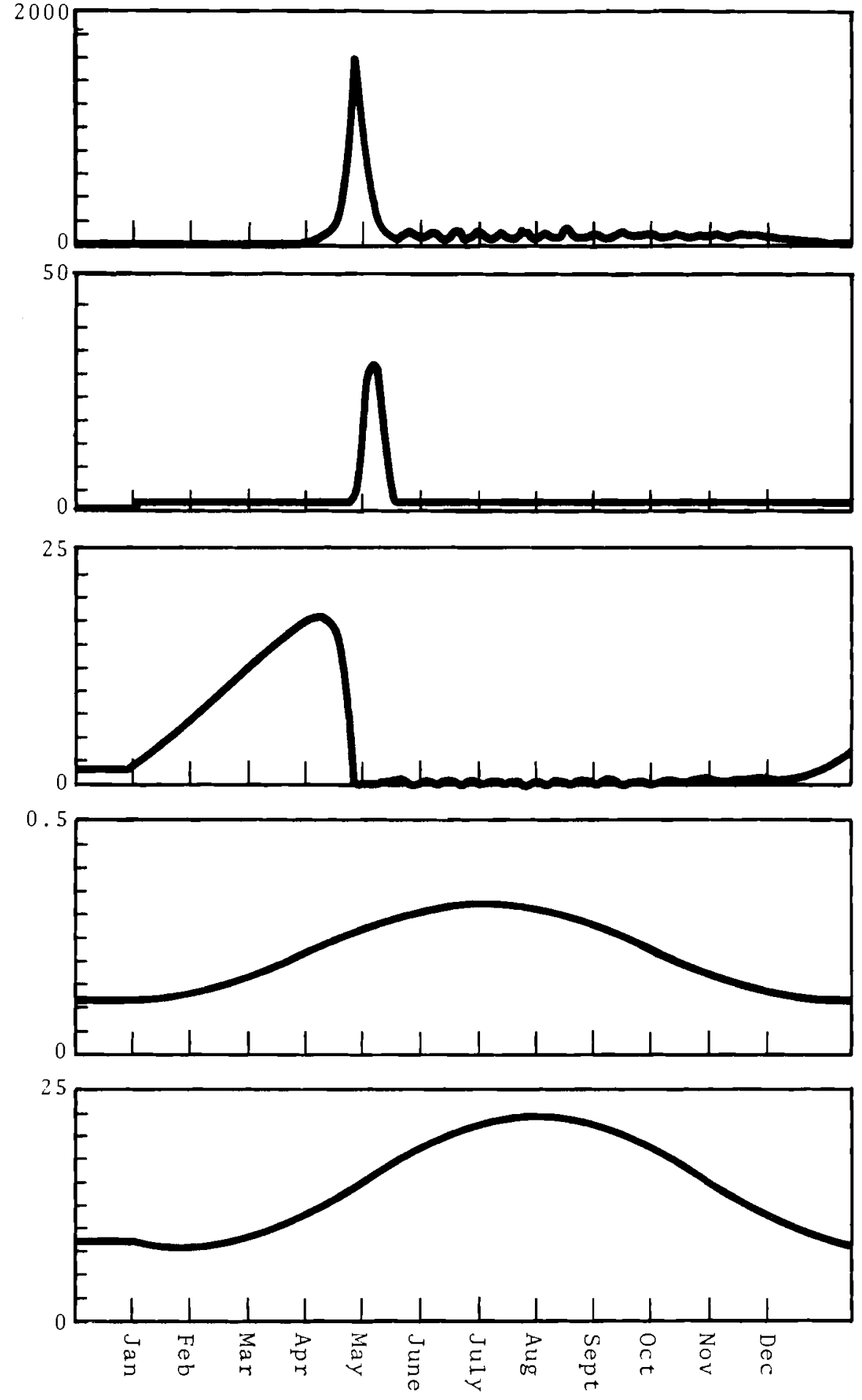

FIGURE 5. Graph Showing the Annual

Cycle of Estuarine Phytoplankton and Zooplankton with Parameter Values

Adjusted so That the Temperature

Varies $\pm 8{ }^{\circ} \mathrm{C}$ Rather than the Normal $\pm 9{ }^{\circ} \mathrm{C}$ 
Figure 6 shows the effect of an $8 \%$ increase in phytoplankton death rate. The spring bloom is delayed about one week and it is much larger in magnitude. This result is due to the much lower winter population levels reached due to increased death rate. The lowered winter levels allow for a very large buildup in nutrient, which results in the retarded, but large, "spring algal bloom."

Figure 7 shows the effects of $12 \%$ increase in zooplankton death rate. The increased death rate in zooplankton results in a larger "spring algal bloom" and a greater peak in zooplankton population.

Figure 8 shows the effects of an $8 \%$ increase in the rate of nutrient influx. As might be expected, the result is a general rise in population level throughout the entire year.

The output of the analog is sometimes limited by the dynamic range of the variables present in ecological simulations. For example, if you were interested in the low levels that the phytoplankton and zooplankton population reached during winter, the analog simulation would not be satisfactory. But in addition to programming the ecosimulation for the analog, digital simulations can also be prepared in order to compare costs between the analog and digital simulations, to serve as a check of the analog simulation, and, as would be the case with this plankton simulation, to obtain the dynamic range available with a digital simulation. A digital simulation could be written in any of the various simulation languages: MIDAS, MIMIC, and DSL/90, or even FORTRAN IV.
A block diagram of a MIDAS digital simulation of the plankton ecocycle appears in Figure 9. Figure 10 shows the program listing and a sample output. Figure 11 shows the analog circuit used in the simulation of plankton population dynamics.

In the developing of an ecosimulation, such as the one described, it is not just a process of fitting some curves together that will produce a curve similar to the observed data. Equations are used only if they reasonably describe the actual biological mechanisms involved. If it is necessary to introduce an equation which does not presently describe any known ecological mechanism, it is done only if there is some known or proposed mechanism which has not been simulated. The equation is retained only when the mechanisms it was thought to describe has been verified, and when it has been verified that the equation adequately describes the mechanism. For example, you might wonder why the nutrient $N$ is limited to 0.5 in the equation describing phytoplankton growth. The mechanism involved here is that only a certain concentration of nutrient is needed to sustain phytoplankton growth and any concentration above $\mathrm{N}^{\mathrm{LIM}}$ is superfluous.

In many ecological systems, all of the parameter values are not known; but on the analog computer, one year can be reduced to ten seconds, one second, or even less; so that by changing the values of the unknown parameter while the computer is computing at the rate of one year a second, the output can be changed to correspond to ecological 


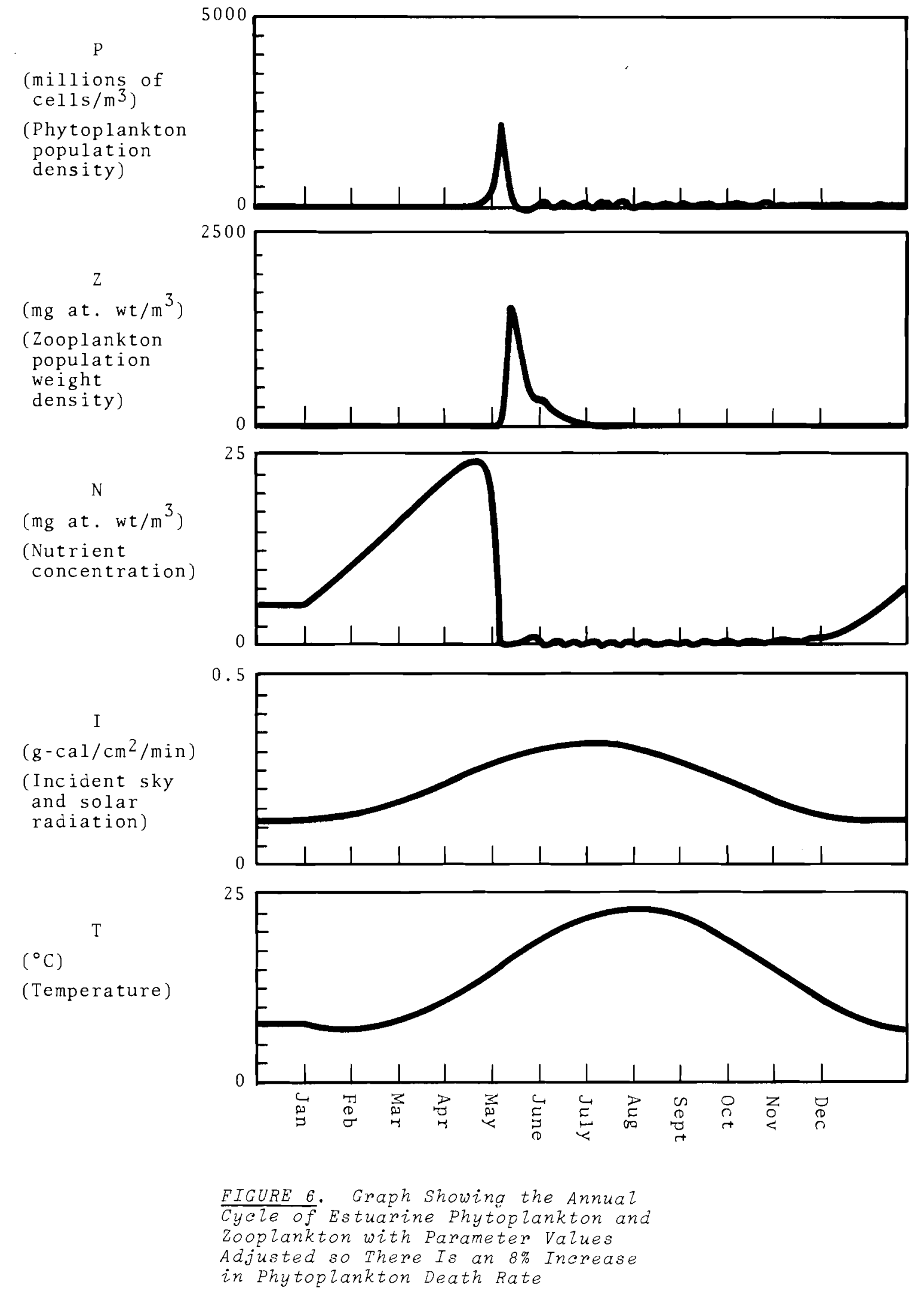




\section{$\mathrm{P}$}

(millions of cells $/ \mathrm{m}^{3}$ )

(Phytoplankton population density)

\section{$\left(\mathrm{mg} / \mathrm{m}^{3}\right)^{\mathrm{Z}}$}

(Zooplankton population we ight density)

\section{$\mathrm{N}$}

(mg at. wt $/ \mathrm{m}^{3}$ )

(Nutrient

concentration)

I

$\left(\mathrm{g}-\mathrm{cal} / \mathrm{cm}^{2} / \mathrm{min}\right)$

(Incident sky and solar radiation)

$\mathrm{T}$

$\left({ }^{\circ} \mathrm{C}\right)$

(Temperature)
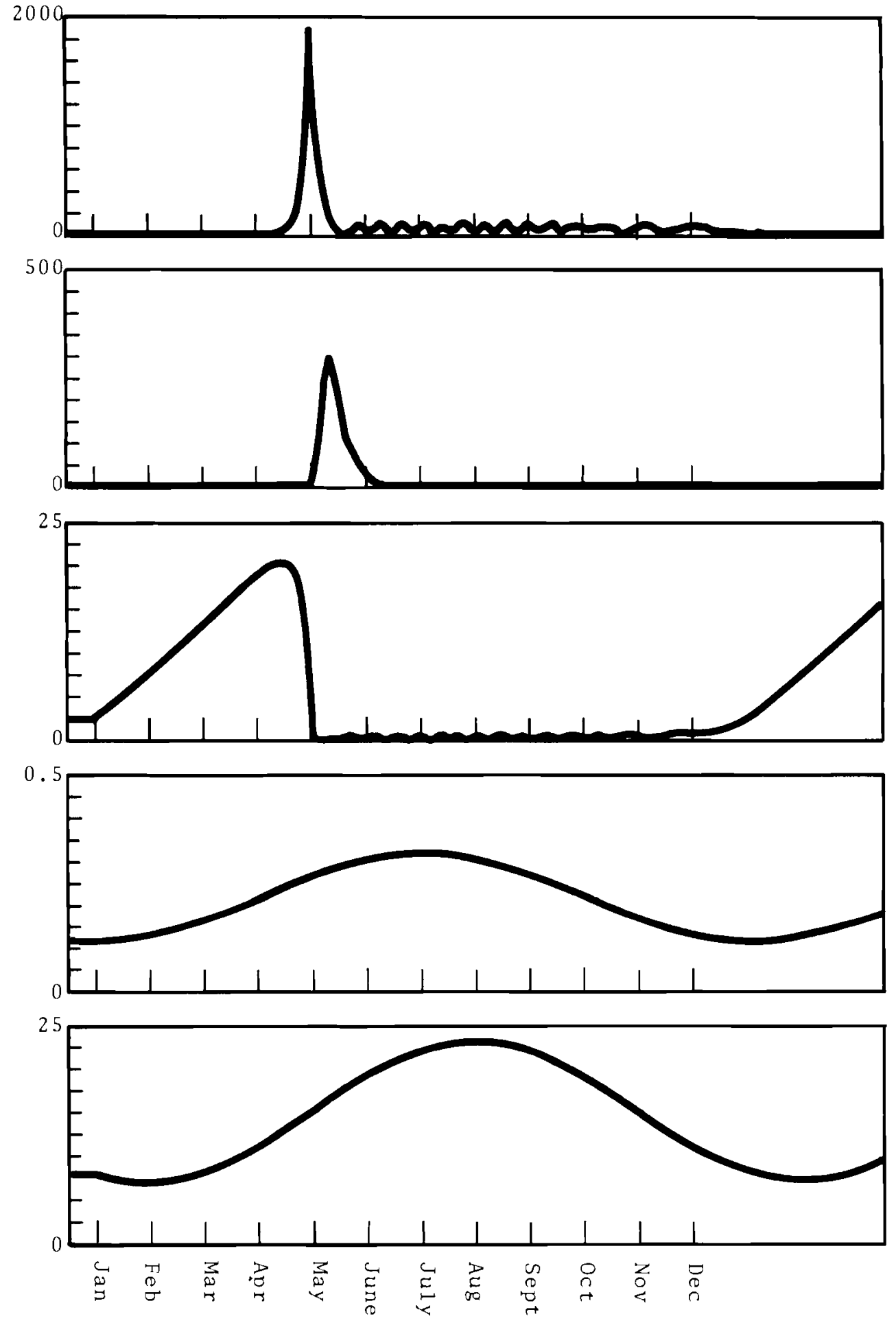

FIGURE 7. Graph Showing the Annual

Cycle of Estuarine Phytoplankton and

zooplankton with Parameter Values

Adjusted so There Is a 12\% Increase

in Zooplankton Death Rate 

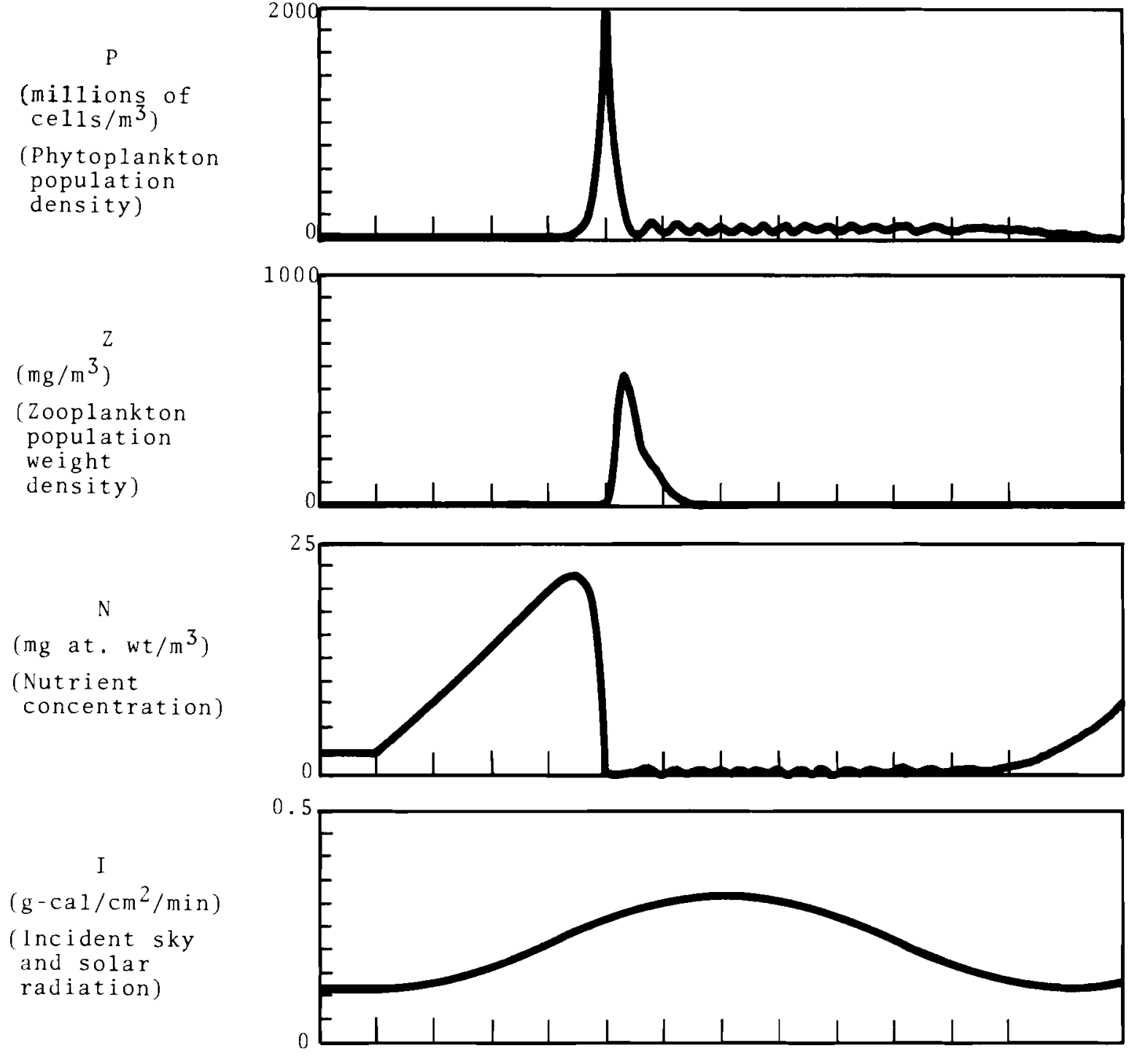

$\left(\mathrm{g}-\mathrm{ca} 1 / \mathrm{cm}^{2} / \mathrm{min}\right)$

(lncident sky

and solar

radiation)

$\left.{ }^{\circ} \mathrm{C}\right)$
$($ Temperature $)$

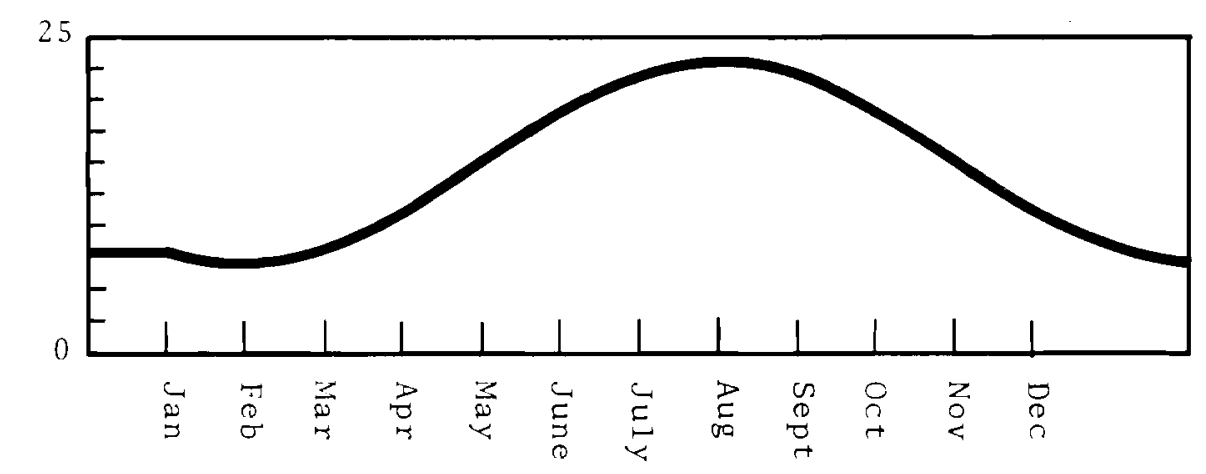

FIGURE 8. Graph Showing the Annual

Cycle of Estuarine Phytoplankton and

Zooplankton with Earameter Values

Adjusted so There Was an $8 \%$ Increase

in Nutrient Influx 


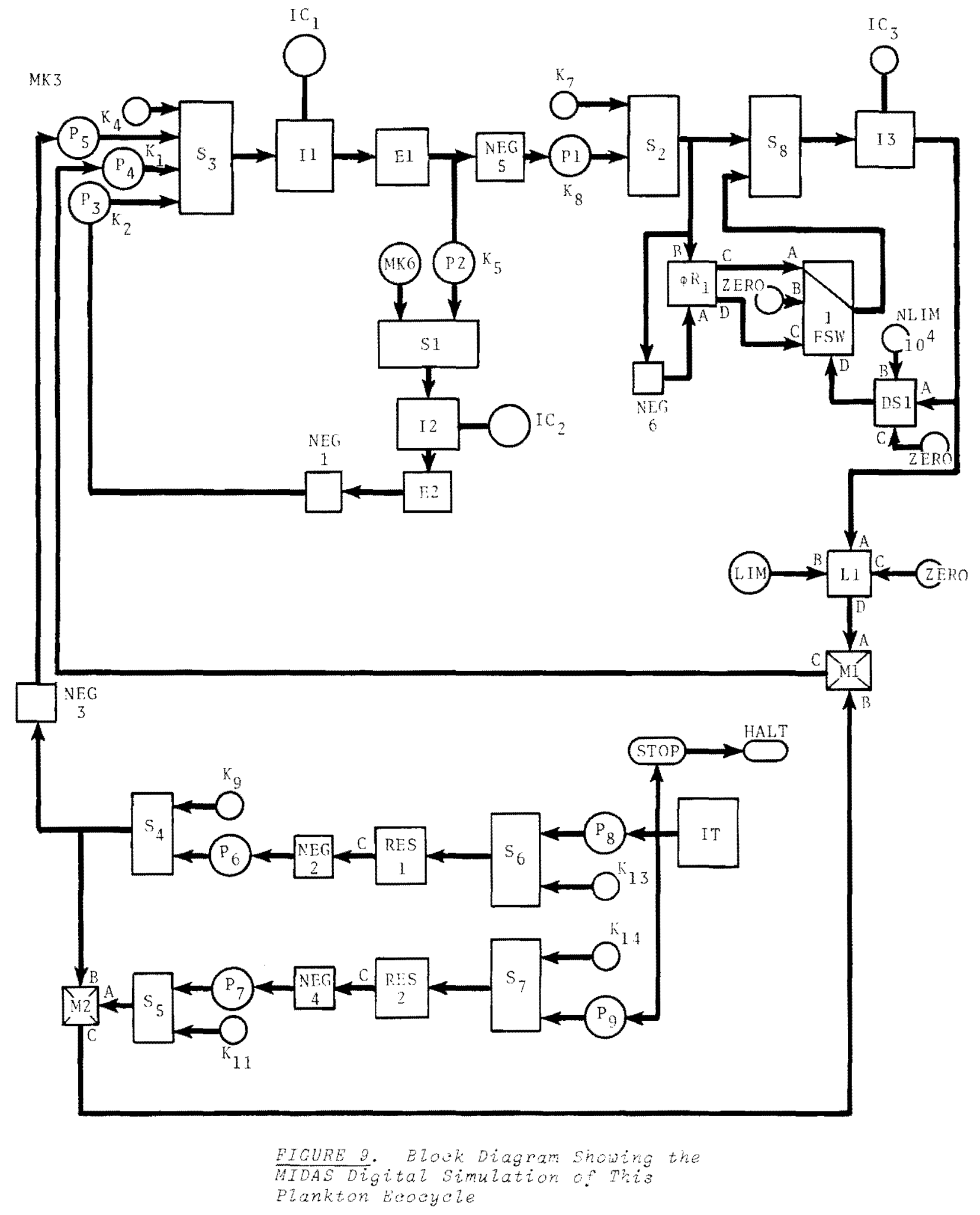




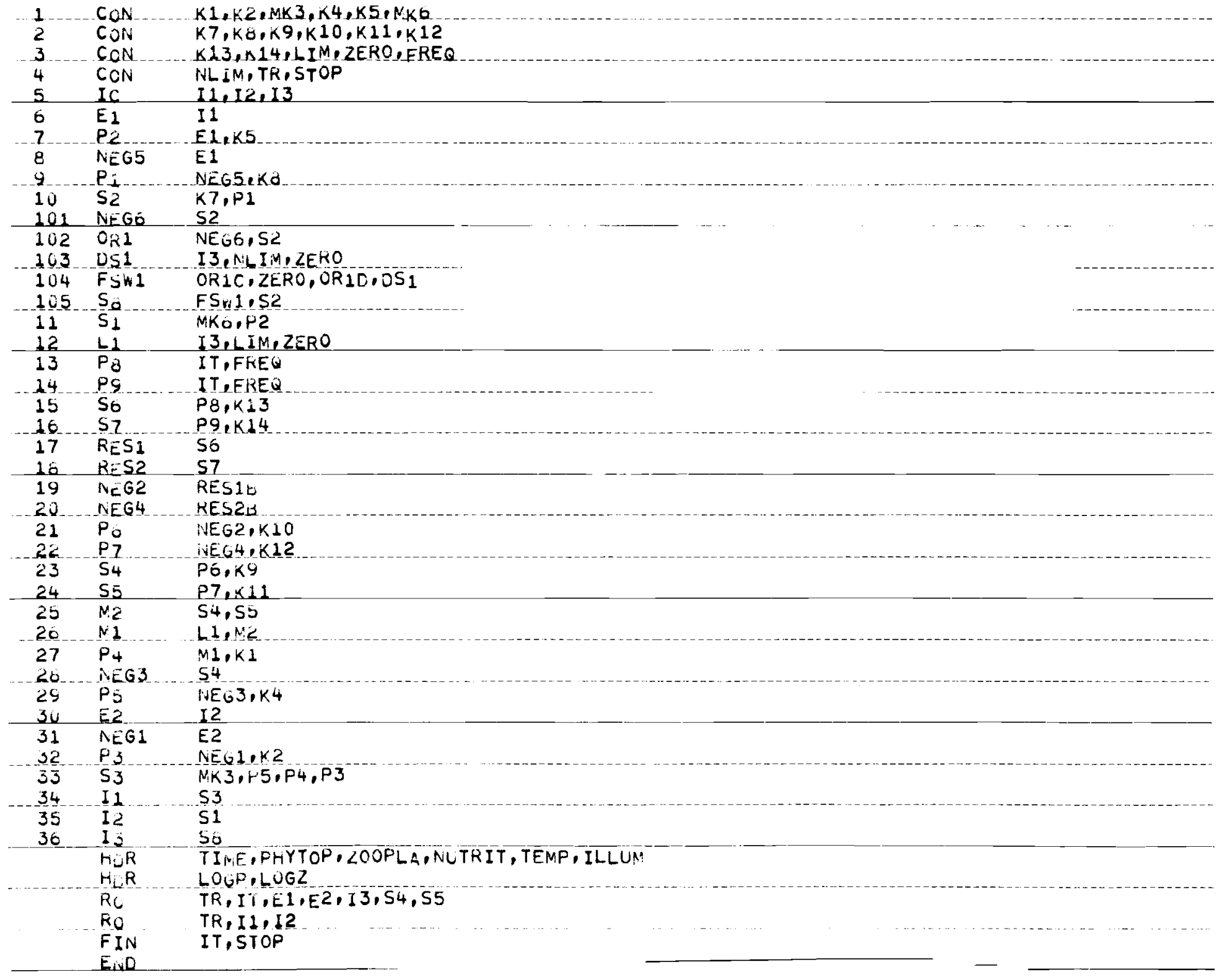




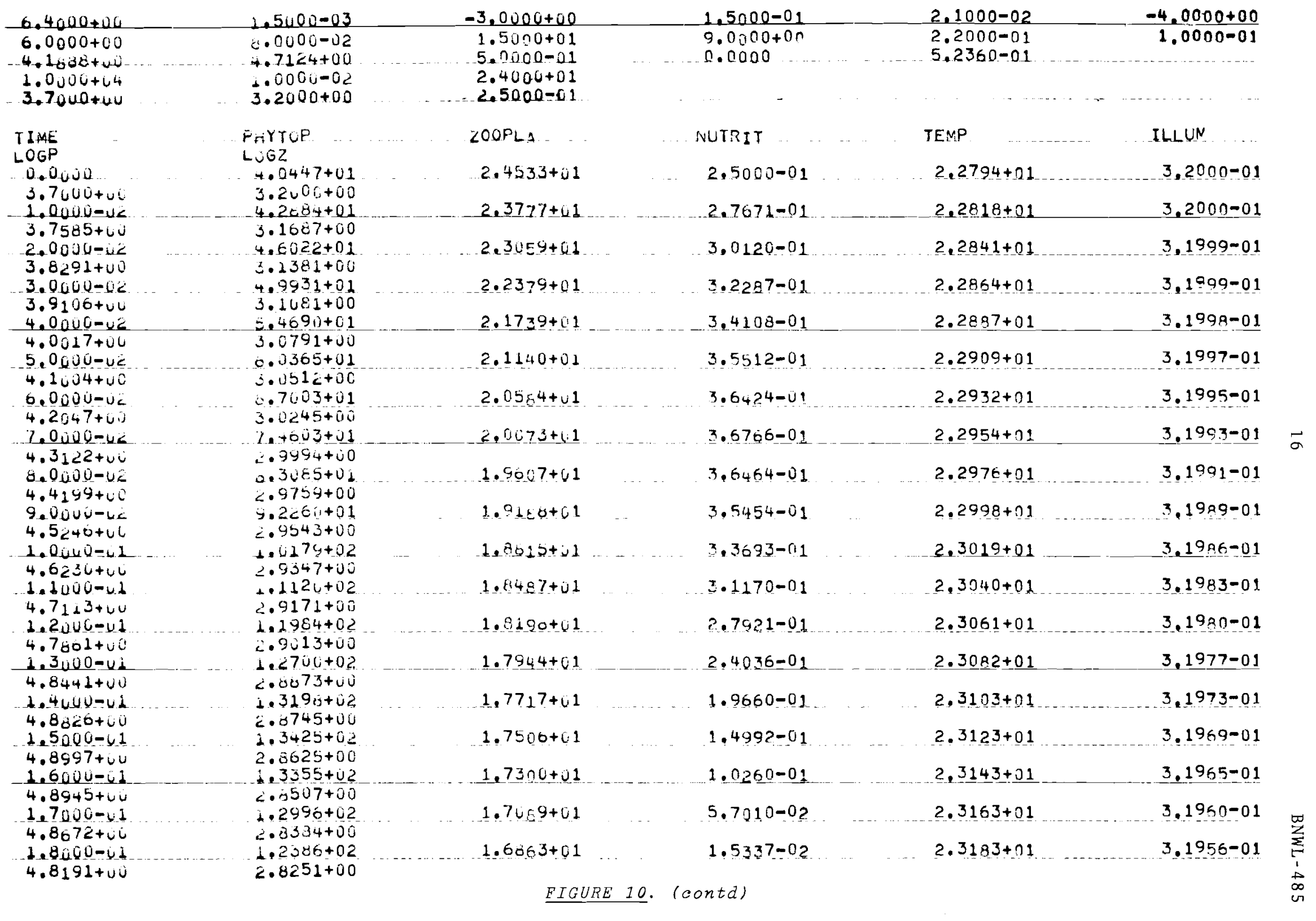




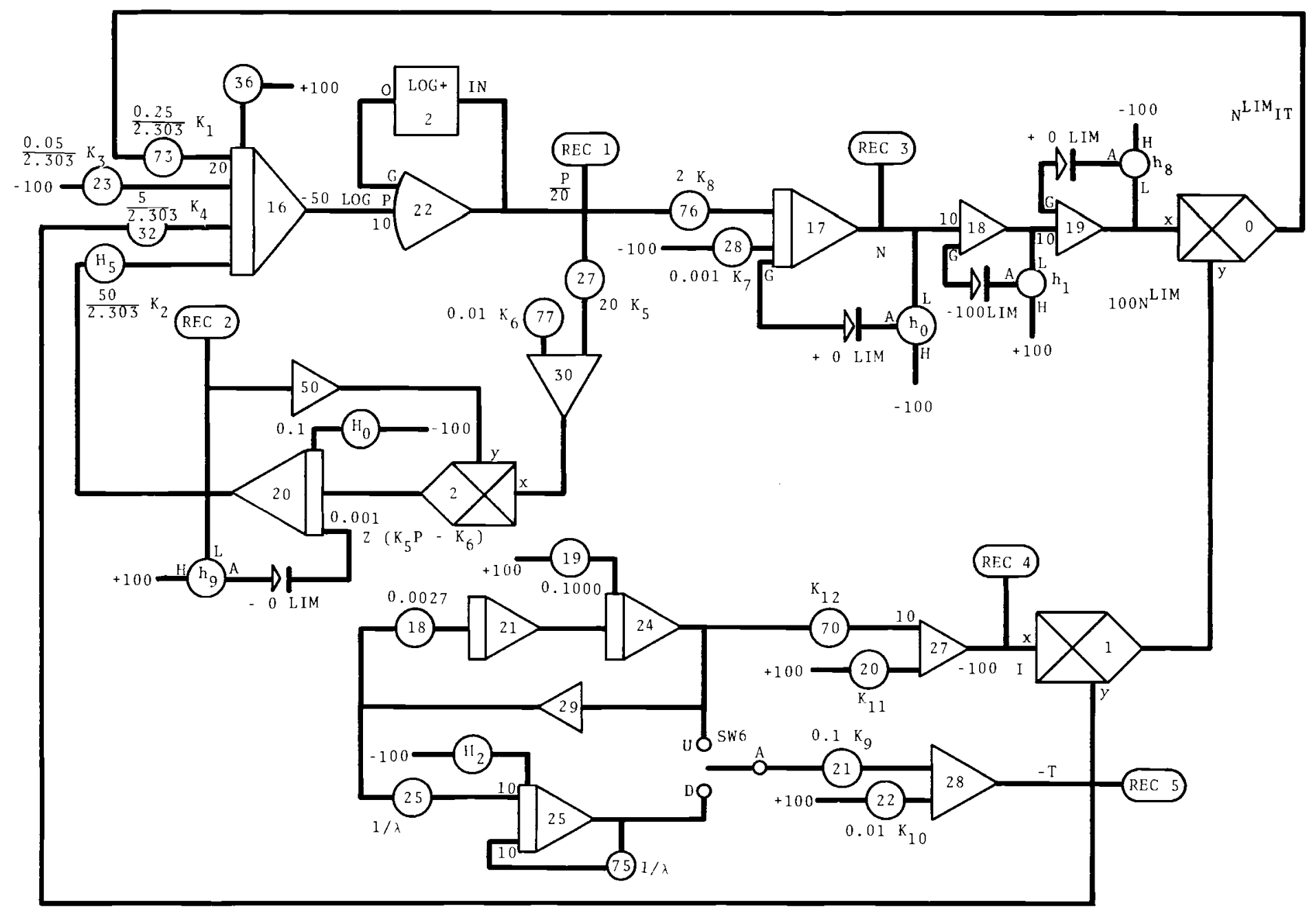

FIGURE 11. Diagram Showing the Analog

Circuit Used in the Simulation of 
data. These tuned values are then indicative of the values of the missing parameters. The values of the parameters can then be verified by ecological measurements when possible. Agreement between computer obtained parameters and ecological measurements serves to validify the simulation.

If disagreement occurs between computer obtained parameters and ecological measurements, it indicates that all the ecological mechanisms were not taken into account. This disagreement can then result in the discovery of new mechanisms or the verification of presently unaccepted ecological mechanisms which have been proposed. This indicates another value of ecosimulation. Simulation of an ecosystem can serve as a check of our understanding of ecological systems as a whole. The developing and validification of an ecosimulation can point out mechanisms that have been neglected, and mechanisms that have been overemphasized. Once obtained, the simulation can, as demonstrated, be a useful device in prediction of the effects of parameter changes.

\section{REFERENCES}

1. R. S. Davidson and A. B. Clymer. "The Desirability and Applicability of Simulating Ecosystems," Annals New York Academy of Sciences, vol. 128, Article 3, Pp. 790-794, 1966. 


\title{
DISTR I BUT I ON
}

\author{
No. of \\ Copies \\ 3 \\ AEC Library, washington \\ H. D. Bruner \\ C. L. Dunham \\ W. Lotz \\ 1 AEC Oak Ridge Operations \\ Office \\ 8 AEC Richland Operations \\ Office \\ L. C. Brazley \\ W. M. Harris \\ E. B. Jackson \\ C. L. Robinson \\ R. K. Sharp \\ M. W. Tiernan \\ R. D. Wildman \\ Technical Information \\ Library \\ 270 Division of Technical \\ Information Extension \\ $57 \quad$ Battelle-Northwest \\ F. W. Albaugh \\ W. J. Bair \\ R. D. Benham (10) \\ C. A. Bennett \\ J. J. Cadwe 11 \\ B. G. Christensen
}

Battelle-Northwest (contd)

C. R. Cole (10)

C. C. Coutant

C. E. Cushing

G. M. Dalen

J. M. Dean

P. J. Dionne

G. E. Driver

L. L. Eberhardt

S. W. Fowler

R. B. Hall

W. A. Haney

W. C. Hanson

J. F. Honstead

R. T. Jaske

H. A. Kornberg

K. H. Larson

W. H. Matchett

R. E. Nakatani

I. C. Ne1son

J. A. Nelson

H. M. Parker

R. S. Paul

H. W. Slater

B. O. Stuart

W. L. Templeton

C. R. Watson

D. C. Worlton

Technical Information Files (5)

Technical Publications (1) 